Article

\title{
Bioremediation of Hydrocarbon-Polluted Soil: Evaluation of Different Operative Parameters
}

\author{
David Javier Castro Rodríguez ${ }^{1}$ (), Omar Gutiérrez Benítez ${ }^{2}$, Enmanuel Casals Pérez ${ }^{2}$, Micaela Demichela ${ }^{1}$ (), \\ Alberto Godio $^{3}($ ) and Fulvia Chiampo $1, *$ (1)
}

check for

updates

Citation: Castro Rodríguez, D.J.;

Gutiérrez Benítez, O.; Casals Pérez,

E.; Demichela, M.; Godio, A.;

Chiampo, F. Bioremediation of

Hydrocarbon-Polluted Soil:

Evaluation of Different Operative

Parameters. Appl. Sci. 2022, 12, 2012.

https://doi.org/10.3390/

app12042012

Academic Editor: Mauro Marini

Received: 31 December 2021

Accepted: 11 February 2022

Published: 15 February 2022

Publisher's Note: MDPI stays neutral with regard to jurisdictional claims in published maps and institutional affiliations.

Copyright: (C) 2022 by the authors. Licensee MDPI, Basel, Switzerland. This article is an open access article distributed under the terms and conditions of the Creative Commons Attribution (CC BY) license (https:// creativecommons.org/licenses/by/ $4.0 /)$.
1 Department of Applied Science and Technology, Politecnico di Torino, Corso Duca Degli Abruzzi 24, 10129 Torino, Italy; david.castro@polito.it (D.J.C.R.); micaela.demichela@polito.it (M.D.)

2 Department of Engineering and Environmental Management, Centro de Estudios Ambientales de Cienfuegos (CEAC), Post Mail 5, Ciudad Nuclear 59350, Cuba; omar@gestion.ceac.cu (O.G.B.); ecperez@gestion.ceac.cu (E.C.P.)

3 Department of Environment, Land and Infrastructure Engineering, Politecnico di Torino, Corso Duca Degli Abruzzi 24, 10129 Torino, Italy; alberto.godio@polito.it

* Correspondence: fulvia.chiampo@polito.it; Tel.: +39-011-090-4685

\begin{abstract}
The bioremediation of soils polluted with hydrocarbons demonstrated to be a simple and cheap technique, even if it needs a long time. The current paper shows the application of statistical analysis, based on two factors involved in the biological process at several levels. We focus on the Design of Experiments (DOE) to determine the number and kind of experimental runs, whereas the use of the categorical factors has not been widely exploited up to now. This method is especially useful to analyze factors with levels constituted by categories and define the interaction effects. Particularly, we focused on the statistical analysis of (1) experimental runs carried out at laboratory scale (test $\mathrm{M}$, in microcosm), on soil polluted with diesel oil, and (2) bench scale runs (test B, in biopile), on refinery oil sludge mixed with industrial or agricultural biodegradable wastes. Finally, the main purpose was to identify the factor's significance in both the tests and their potential interactions, by applying the analysis of variance (ANOVA). The results demonstrate the robustness of the statistical method and its quality, especially when at least one of the factors cannot be defined with a numerical value.
\end{abstract}

Keywords: bioremediation; microcosms; biopiles; statistical analysis; categorical factors

\section{Introduction}

Industrial development has caused a dramatic increase in the amount of crude oil used. Consequently, the rapid expansion of crude oil industries has led to the generation of large volumes of hydrocarbons that need attention due to their environmental and health impacts [1].

Pollution by hydrocarbons is associated with different industrial activities which may harm the environment and human health [2]. It is generally accepted that this kind of pollution has an anthropogenic origin, often due to accidental spill from production units and transport pipelines, leakages from storage facilities and underground tanks, mining, human activities in the production, transportation, and improper or illegal behaviours in waste treatment and disposal [3-5].

Despite several regulations and great care for operational safety, the possibility of the uncontrolled release of petroleum products still exists [6]. Indeed, there is growing public concern about the large volume of hydrocarbons that can be inadvertently or deliberately emitted into the environment $[5,7,8]$.

These contaminants can be accumulated in soil due to their low degradation rates, affecting the physical, physiological, and biochemical properties of this valuable resource [9-11]. Furthermore, hydrocarbon pollution poses serious risks to human health [12-15], due to the toxic effects (e.g., mutagenicity and carcinogenicity) and the capability to move through the 
food chain [16,17]. Hence, special attention is required not only to remediate this pollution and prevent their threats to humans and ecosystems but also to recover the polluted areas and give them back to local communities for safe use [18-20].

In soil remediation, the main target is the removal of pollutants to the maximum extent, ensuring that the final concentration will not be higher than the acceptability threshold [11] Since most of the hydrocarbons are biodegradable, bioremediation processes have attracted widespread interest to clean up contaminated areas degrading hydrocarbons into less toxic forms $[11,21,22]$. In this sense, numerous studies have demonstrated that bioremediation can constitute a highly attractive, pioneering, and environmentally friendly technology, based on the use of microorganisms to degrade specific contaminants [11,20,23]. In addition, bioremediation needs simple equipment and low-cost techniques, compared with other chemical and physical methods [24,25].

Bioremediation is an emerging and sustainable technique that can either occur naturally (natural attenuation) or be enhanced by introducing nutrients (biostimulation) or microorganisms (bioaugmentation) [26,27]. Biostimulation has proven to be one of the best solutions in terms of easiness and management compared to the achieved results $[10,28]$. It consists of the improvement of environmental conditions from a nutritional point of view. In addition, biostimulation presents a noticeable advantage in comparison with other alternatives, because the microorganisms are already adapted to the site conditions [27].

Although different approaches have been developed for the enhancement of microbial growth to increase the hydrocarbon remotion [27], the methods used to evaluate the influence of different operative conditions are not yet standardized.

Previous studies have shown how mathematical models can be developed from experimental data $[29,30]$. Mathematical techniques especially used in quality control [31,32] can also be applied successfully to bioremediation processes, setting up the hypotheses and requirements as a statistical experimental array. Various authors agree with the utility of experimental design to evaluate the biodegradation process $[5,11]$. This approach constitutes a useful structured method applicable to any of the stages of the process research and development.

On the other hand, according to the criteria given by various studies [11,33-35], it can be useful to integrate the kinetics of the process to forecast scenarios of remediation activities, considering the time to obtain an acceptable pollutant removal.

The goal of the current study was to evaluate the hydrocarbon bioremediation process using a structured method that sets the experimental requirements and enables not only the robust assessment of different conditions of interest but also included the degradation kinetics analysis. The comparison of two cases in different conditions of pollution, scales, and biostimulation technologies was herein systematized.

In bioremediation processes, several researchers have adopted the Design of Experiments (DOE) to optimize the number and kind of experimental runs, whereas the use of the categorical factors has not been widely exploited up to now. This method is especially useful to analyze factors with levels constituted by categories and define the interaction effects.

Particularly, we focused on the statistical analysis of (1) experimental runs carried out at laboratory scale (test $\mathrm{M}$, in microcosm), on soil polluted with diesel oil, and (2) bench scale runs (test $B$, in biopile), on refinery oil sludge mixed with industrial or agricultural biodegradable wastes. Finally, the main purpose was to identify the factor's significance in both the tests and their potential interactions, by applying the analysis of variance (ANOVA). The analysis of variance was herein used to describe the relations among variables: respectively, time, water content, ratio $\mathrm{C} / \mathrm{N}$ for the test $\mathrm{M}$, and time, kind of organic biodegradable wastes for the test $\mathrm{B}$. In both tests, the response variable was the residual concentration of hydrocarbons.

This method was previously applied [35], and the results achieved in this study supported its robustness at different conditions of pollution, scales, and techniques. 


\section{Materials and Methods}

This section offers both the study cases description and the structured procedure adopted to evaluate them. Figure 1 presents a heuristic diagram with the steps of this procedure. Then, a description of each step and details is provided.

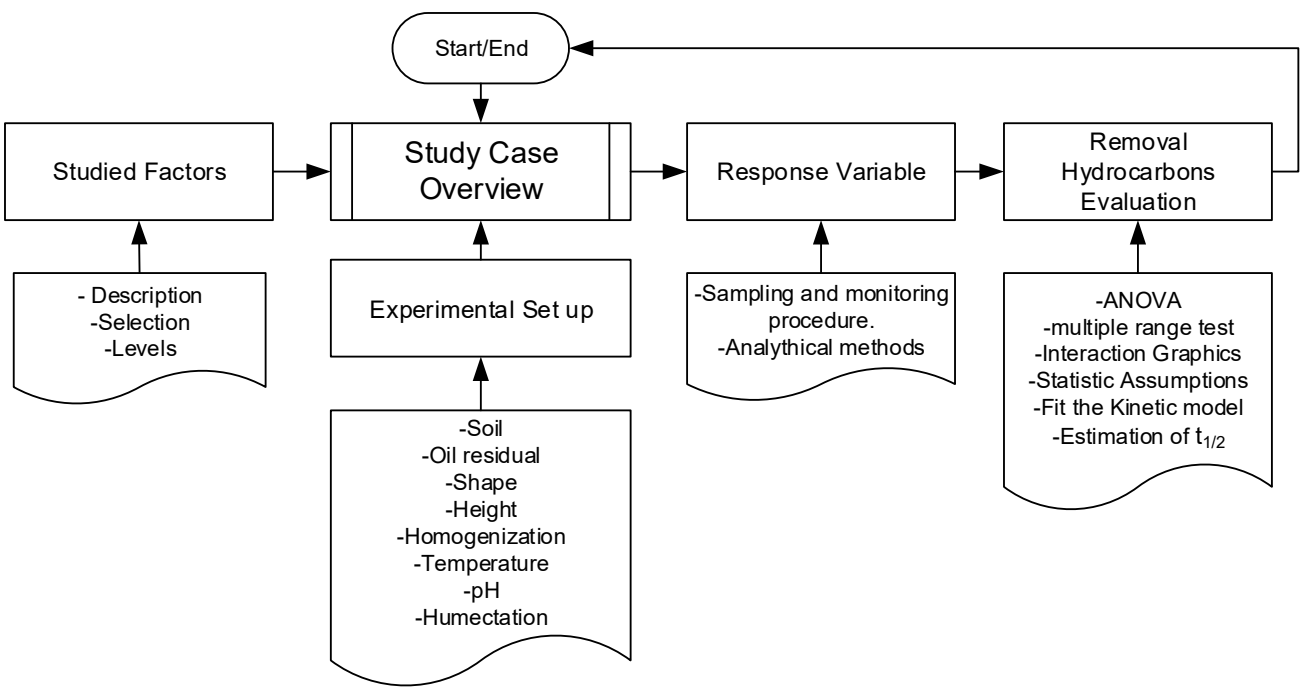

Figure 1. Heuristic diagram with the steps of the procedure to evaluate hydrocarbons bioremediation.

\subsection{Study Cases Overview}

The evaluation of two study cases with hydrocarbon pollutants, different scales, and biostimulation operation was systematized. Then, two categorical multifactor arrays were designed, randomized, and performed. This kind of design is useful for situations where the main interest is to compare levels of two or more categorical factors. The procedure creates a multilevel factorial design with runs at each combination of the factor levels. In both cases, the effects of two factors on the single response variable total petroleum hydrocarbons (TPH) concentration were assessed. For each study case, the experimental runs are described, namely:

- $\quad$ Microcosms test (test M), based on a small amount of polluted soil (200 g)

- $\quad$ Bench test (test B), based on a larger polluted mass (around $38 \mathrm{~kg}$ ).

\subsubsection{Microcosms Test}

This test analyzed the evolution of the residual TPH concentration and the microbial activity in a series of soil microcosms, artificially polluted with commercial diesel oil and cleaned up by indigenous aerobic microorganisms. As a biological strategy, biostimulation (the addition of nutrients suitable for the microbial metabolism) was adopted, in particular, a mineral salt medium for bacteria was chosen.

The experimental runs at the laboratory scale constitute the preliminary step to define the optimal operative conditions to use for larger scales.

\subsubsection{Bench Test}

In this test, the refinery oily sludge was chosen as a contaminant. This selection was based on the evidence that the generation of oily sludge is associated with frequent operations within the oily industry such as oil production, pretreatment, processing, water separation, and maintenance of storage tanks [15,36]. The test applied the ecotechnique of biopiles at a bench scale to bioremediate hydrocarbons. This technique can be more efficient than others to remove hydrocarbons in sludges [2].

Furthermore, the system efficiency was based on the concept of circular economy, adding industrial organic or agricultural wastes as a nutrient to stimulate microorganisms 
in soils $[19,37]$. The amendments or bulking agents were also thought to increase soil porosities and contribute to soil moisture retention [33,38,39].

\subsection{Studied Factors}

In the experimental runs, two factors were studied. For both tests, a 6-levels categorical factor called "Treatment" was defined.

Likewise, in both the tests, the other factor was the "Time", defined at 5 levels. Each level corresponded to the time when the residual TPH concentration was monitored after the run started. This second factor was chosen under the hypothesis that the different treatments could have interactions during the bioremediation.

\subsubsection{Factors and Levels for the Test $\mathrm{M}$}

The categorical factor levels, $\mathrm{Mi}(\mathrm{i}=1,2 \ldots 6)$, correspond to a combination of values water content $(\mathrm{WC} \%)$ and carbon to nitrogen ratio $(\mathrm{C} / \mathrm{N})$. These combinations are labelled: M1(8 WC\%-120 C/N); M2 (8 WC\%-180 C/N); M3 (12 WC\%-120 C/N); M4 (12 WC\%$180 \mathrm{C} / \mathrm{N})$; M5 (15 WC\%-120 C/N); M6 (15 WC\%-180 C/N). The values for WC\% and C/N ratio correspond to the values giving the optimal biological metabolism [11].

The factor "Time" for the test M, Tmi ( $\mathrm{i}=1,2 \ldots 5)$, corresponds to $0,15,70,112,131$ days after the run start.

\subsubsection{Factors and Levels for the Test $B$}

The categorical factor levels, $\mathrm{Bi}$, correspond to the different treatments of the biopiles technique. Each run had a supplement of a specific organic waste as an additive bulking agent in the mixtures of soil and hydrocarbons.

The levels were labelled as follows: B1 (sugarcane bagasse); B2 (sugarcane filter cake); B3 (sawdust); B4 (coffee pulp); B5 (beef manure); B6 (Thalassia testudinum residues). These organic wastes were chosen based on the following technical, economical, and environmental criteria: (i) chemical composition reported in the literature; (ii) volume generation by the local industry and agriculture; (iii) current consumption; (iv) logistical aspects related to collection, transportation, and pretreatment; (v) aspects related to the operational and environmental safety caused by working with them. The factor "Time" for test $\mathrm{B}, \mathrm{Tbi}(\mathrm{i}=1,2 \ldots 5)$, corresponds to $0,60,90,150,240$ days after the run start.

\subsection{Experimental Setup}

\subsubsection{Test $\mathrm{M}$}

Six soil microcosms were set up in sealed glass jars (volume $=0.2 \mathrm{~L}$ ) with $200 \mathrm{~g}$ of soil (layer height $=3 \mathrm{~cm}$ ), adding a mineral salt medium for bacteria (MSMB). The medium composition is reported in a previous study [11]. The dosage of MSBM solution was used to change the water content and the carbon to nitrogen ratio.

Sandy soil was used, after sieving according to ASTM C method 136. For the runs, just the particles with a size distribution between 0.15 and $2 \mathrm{~mm}$ were used. The main characteristics of this soil are: porosity $=40-42 \%$ by volume; density $=2700 \mathrm{~kg} \cdot \mathrm{m}^{-3}$; negligible water content.

The tested soil was spiked with commercial diesel oil (concentration equal to $70 \mathrm{~g} \cdot \mathrm{kg}^{-1}$ of soil), followed by mixing the compounds with a laboratory spoon for $5 \mathrm{~min}$.

The jars were kept in the laboratory, at a constant temperature equal to $20^{\circ} \mathrm{C}$. Each jar was aerated 2-3 times a week by manual mixing with a laboratory spoon for $5 \mathrm{~min}$.

\subsubsection{Test $\mathrm{B}$}

This test was carried out inside an industrial warehouse, roofed, with a concrete floor, and provided with open windows, adapted as an experimental polygon for research at bench scale. Here, 24 experimental biopiles were prepared within identical polyethylene basins with dimensions of $1.10 \mathrm{~m}$ long and $0.95 \mathrm{~m}$ wide. Each basin, acting as a container, was separated from the surrounding ones to avoid the mix of materials and leakage. The 
moisture content was checked every 4 days, and every two weeks the processing material was homogenized in its basin with manual means, to achieve aeration of the mixture.

The layout of the experimental units was selected using a simple random procedure, assigning a randomized number to each biopile that matched a specific position in the experimental polygon area. The distribution is shown in Figure 2.

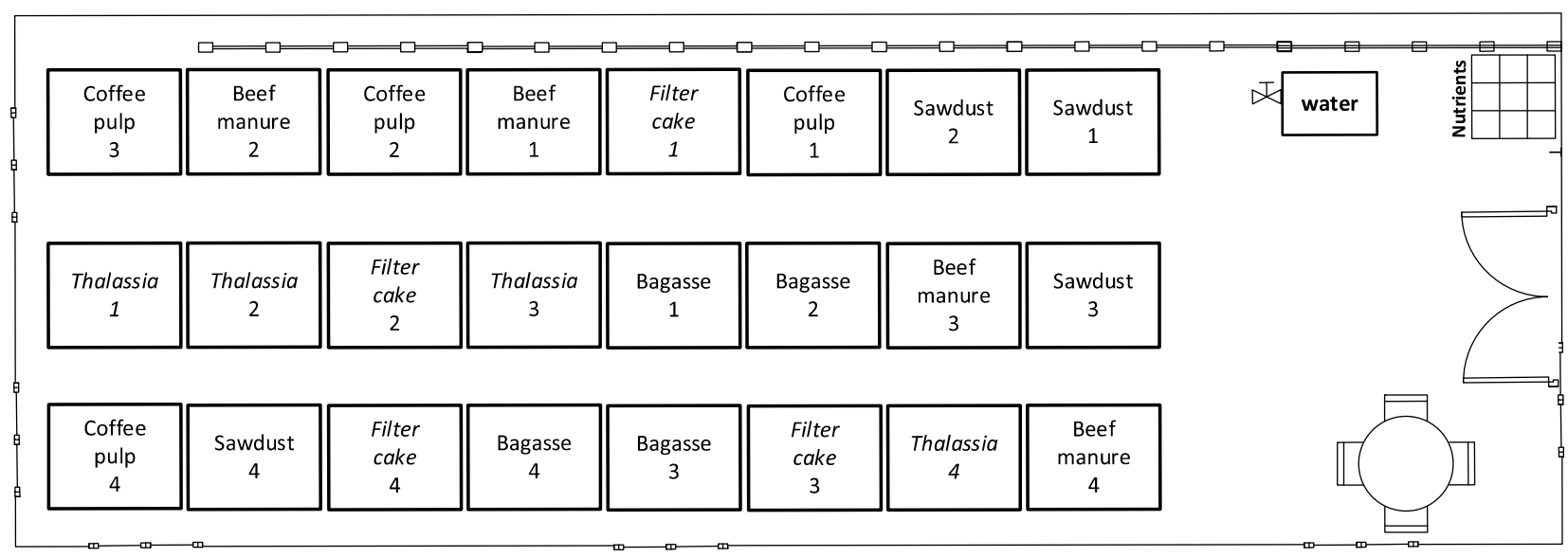

Figure 2. Distribution of the biopiles in test B.

The biopiles were set up taking into account both the technical and logistical necessities deployed by Castro et al. [40] and the guidelines for construction design of typical biopiles given by EPA [41]. Each biopile was shaped like a truncated pyramid, with a height around $0.2 \mathrm{~m}$ and an angle of about $45^{\circ}$ between the lateral pyramid faces and the lower base. The starting total mass of each biopile has been chosen equal to $38 \mathrm{~kg}$, corresponding to $30.3 \mathrm{~kg}$ of soil, $3.04 \mathrm{~kg}$ of additive bulking agent, and $4.66 \mathrm{~kg}$ of oily sludge. The initial TPH concentration of each experimental unit was estimated equal to $9.57 \mathrm{~g} \cdot \mathrm{kg}^{-1}$ of the mixture (soil, hydrocarbons, and additive bulking agent of wet base), calculated by mass balance from the composition of the ingredients. In each biopile, the ratio $\mathrm{C} / \mathrm{N}$ was equal to 10, according to the criteria given by EPA [41]. This parameter was achieved by dosing a solution containing urea and ammonium nitrate and mixing it with the processing material.

The water content for all the experimental units was fixed at $20 \%$ by weight. Details of the biopile design are given in a previous paper [42].

The $\mathrm{pH}$ was kept in the range $6-8$, while the temperature was in the range $16-30{ }^{\circ} \mathrm{C}$, according to the seasonal temperature in Cuba, as reported in a previous study [43]. Monitoring of temperature, $\mathrm{pH}$, and water content, as well as homogenization, aeration, and handling procedures, were previously described [33].

A typical greyish-brown soil from the central region of Cuba was used (density $\left.=1190 \mathrm{~kg} \cdot \mathrm{m}^{-3}\right)$. For the soil classification, the Cuban standards [44,45] based on ASTM D 422-63 (Standard Test Method for Particle-Size Analysis of Soils) and ASTM D2487 (Standard Practice for Classification of Soils for Engineering Purposes) were applied. The soil was classified as silty-clay-sand with low plasticity and moderate permeability. The soil was sieved using an industrial mesh for particles smaller than $4.75 \mathrm{~mm}$, according to the previously mentioned Cuban standards.

As aforesaid, as a pollutant for the biopiles, an oily sludge deriving from the settler of a Cuban refinery wastewater treatment was chosen. Due to its hazardousness, the sludge cannot be disposed in the environment, as imposed by the national standard [46].

For the sake of clearness, Table 1 reports the information for both tests. 
Table 1. Operative conditions for the studied tests.

\begin{tabular}{|c|c|c|}
\hline Operative Conditions & Microcosms (Test M) & Biopiles (Test B) \\
\hline Response variable & $\mathrm{TPH}$ & $\mathrm{TPH}$ \\
\hline \multirow{6}{*}{$\begin{array}{l}\text { Factor } 1 \text {-Treatments } \\
\text { (6 categorical levels) }\end{array}$} & M1 (8 WC\%-120 C/N) & B1 (sugarcane bagasse) \\
\hline & M2 (8 WC\%-180 C/N) & B2 (sugarcane filter cake) \\
\hline & M3 (12 WC\%-120 C/N) & B3 (sawdust) \\
\hline & M4 (12 WC\%-180 C/N) & B4 (coffee pulp) \\
\hline & M5 (15 WC\%-120 C/N) & B5 (beef manure) \\
\hline & M6 (15 WC\%-180 C/N) & B6 (Thalassia testudinum) \\
\hline \multirow{5}{*}{$\begin{array}{l}\text { Factor 2-Time } \\
\text { (5 levels) }\end{array}$} & 0 & 0 \\
\hline & 15 days & 60 days \\
\hline & 70 days & 90 days \\
\hline & 112 days & 150 days \\
\hline & 131 days & 240 days \\
\hline Mass & $200 \mathrm{~g}$ & $38 \mathrm{~kg}$ \\
\hline Pollutant & Diesel oil & Oily Sludge \\
\hline \multirow{3}{*}{ Water content $(\mathrm{WC} \%)$} & $8 \%$ & \multirow{3}{*}{$20 \%$} \\
\hline & $12 \%$ & \\
\hline & $15 \%$ & \\
\hline \multirow{4}{*}{ Carbon to nitrogen ratio $(\mathrm{C} / \mathrm{N})$} & 60 & \multirow{4}{*}{10} \\
\hline & 120 & \\
\hline & 180 & \\
\hline & 300 & \\
\hline Kind of soil & Sandy soil & Sandy soil \\
\hline $\mathrm{pH}$ & $6-8$ & $6-8$ \\
\hline
\end{tabular}

\subsection{Response Variable}

Through the response variable, the influence of each factor can be defined. In both the tests, the single response variable is the TPH concentration. This parameter was determined by different analytical methods, as described here following.

\subsubsection{Determination of the TPH Concentration in the Test M}

The response variable was measured in sample extracts achieved from each microcosm. The extraction was performed by the EPA method 3546 (moisture 15-30\% b.w.), based on microwave heating, as described in a previous paper [11]. Then, each extract was analyzed twice by the EPA method 8015 to measure the TPH concentration [11].

The monitoring of the TPH concentration was done at $0,15,70,112,131$ days, each time corresponding with one level of the factor "Time".

The experimental design of test $\mathrm{M}$ has combined all the levels of the factors $(6 \times 5)$. Since two replicas were carried out, a total of 60 runs were available, achieving 30 degrees of freedom (Df). The statistical parameters of the DOE were considered statistically consistent with the strengths in the analytical determination method of the TPH concentration.

\subsubsection{Determination of the TPH Concentration in Test B}

The response variable was measured with samples collected from each biopile. Regarding this issue, a procedure was established to standardize the sample collection.

The biopiles were appropriately homogenized before the collection, destroying their initial geometry design (truncated pyramid), and intensively mixing all the mass, emphasizing the destruction of lumps; 5 samples of mass around $100 \mathrm{~g}$, were taken from the four corners of the basin and the centre, alternating between bottom and surface samples.

At last, a quartering was done, and $100 \mathrm{~g}$ was taken for the determination of the TPH concentration. The samples were uniformly dried and grounded as part of the pretreatment 
to increase homogeneity. Then, they were spread on an aluminum foil inside a room at a controlled temperature of $30^{\circ} \mathrm{C}$ for $48 \mathrm{~h}$.

The TPH concentration was determined by adapting the EPA Method 1664 to the biopile system. The analysis is based on the TPH extraction from solid by an organic solvent and evaluation of the TPH mass by gravimetry. This method is reliable when the solid sample is over $5 \mathrm{~g}$ and the TPH concentration is over $0.3 \%$ by weight.

The applied method consists of the extraction of a dry soil sample with $n$-hexane in a microwave at $120^{\circ} \mathrm{C}$ for $20 \mathrm{~min}$. Then, the extract ( $n$-hexane + TPHs) is filtered through a funnel containing anhydrous $\mathrm{Na}_{2} \mathrm{SO}_{4}$. After, the solution is distilled at $85{ }^{\circ} \mathrm{C}$ in a water bath. The residual mass is weighted to estimate the TPH quantity. The TPH concentration is achieved by the ratio of TPH mass to the dry sample soil mass.

The monitoring of the TPH concentration was done at $0,60,90,150,240$ days, corresponding with the levels of the factor "Time".

Test $B$ has combined all the levels of the factors $(6 \times 5)$. There was a total of 120 runs due to four replicas of the experimental array. This ensured 90 degrees of freedom, which were considered statistically robust, compensating for the weakness of the gravimetric determination method if compared to the gas chromatographic one.

\subsection{Hydrocarbon Removal}

\subsubsection{Statistical Analysis}

The statistical analysis checks if the factor Treatments, the factor Time, or both have a statistically significant effect on the TPH concentration. Beforehand, all the data were statistically processed, and the analyses were performed using a confidence level of $95 \%$ employing the professional software STATGRAPHICS Centurion v. 16.1.18. Additionally, the $p$-values were used to test the statistical significance of each tabular analysis developed.

Since the purpose was to identify the factor's significance in both the tests and their potential interactions, the analysis of variance (ANOVA) was applied. The ANOVA table decomposed the variability of TPH concentration into contributions due to both factors.

Then, the multiple range test developed a multiple comparison procedure to determine if the means within the levels of each factor are significantly different from the others. The output identifies the homogenous groups of means assigning to them the same columns of $X$, within each column, the levels containing $X$ form a group of means within which there are no statistically significant differences. Moreover, the graphical output plots the mean of TPH concentration and shows an interval around it for each level of factors. These intervals are based on Fisher's least significant difference (LSD) procedure to discriminate among the means. They are constructed in such a way that if two means are the same, their intervals will partially or overlap 95\% of the time. Any pair of intervals, that do not overlap horizontally, corresponds to a pair of means which have a statistically significant difference.

The interaction plot was developed to analyze the significant effects of interaction on the factor Treatments during the factor Time. The graph deploys lines that represent the different levels of the analyzed factor. If there is no interaction, these lines are parallel.

Finally, the assumptions of normality (frequency histogram fitted to normal distribution), homoscedasticity (residuals vs. predicted values), and independence of the residuals (residuals vs. row numbers) were verified.

\subsubsection{Kinetics Analysis}

The kinetic of the hydrocarbon degradation can be described with the model:

$$
R=\partial C / \partial t=-k \cdot C^{n}
$$

where $R$ is the reaction rate, $C$ is the oily residual concentration in soil, $k$ is the reaction rate constant, and $n$ is the reaction order.

In this study, the first $(n=1)$ and the second-order $(n=2)$ models were considered, due to their good fitting of experimental data, already demonstrated in previous studies $[33,47]$. 
Considering the first-order model $(n=1)$, Equation (1) becomes:

$$
R=\partial C / \partial t=-k \cdot C
$$

and the residual can be achieved by integrating Equation (2) between $t=0$ and $t$ :

$$
C t=C_{0} \cdot e^{-k t}
$$

where $C_{0}$ and $C_{t}$ are, respectively, the oily residual concentration at $t=0$ and $t$, and $k$ is the reaction rate constant.

It can be useful to evaluate the half-life time. This parameter, $t_{1 / 2}$, can be calculated as:

$$
t_{1 / 2}=\ln 2 / k=0.693 / k
$$

In the first-order reaction rate model, $t_{1 / 2}$ does not depend on the initial oil concentration. In the second-order model $(n=2)$, Equation (1) becomes:

$$
R=\partial C / \partial t=-k \cdot C^{2}
$$

Analogously, the oily residue can be expressed by integrating Equation (5) between $t=0$ and $t$ :

$$
1 / C_{t}=\left(1 / C_{0}\right)+k \cdot t
$$

where $k$ is the reaction rate constant.

In this case, the half-life time $t_{1 / 2}$ depends on the initial oil concentration:

$$
t_{1 / 2}=1 / k \cdot C_{0}
$$

Experimental data fitting can give the most suitable order for the process kinetics.

\section{Results}

\subsection{Statistical Analysis}

\subsubsection{Test $\mathrm{M}$}

The decomposition of the variability of the TPH concentration into contributions due to Treatments, Time, and their interaction is presented in Table 2.

Table 2. ANOVA for test $\mathrm{M}$.

\begin{tabular}{cccccc}
\hline Source & $\begin{array}{c}\text { Sum of } \\
\text { Squares }\end{array}$ & Df & $\begin{array}{c}\text { Mean } \\
\text { Square }\end{array}$ & F-Ratio & $p$-Value \\
\hline Main Effects & & & & & \\
Treatments & 537.43 & 5 & 107.47 & 72.21 & 0.000 \\
Time & $16,735.40$ & 4 & 4183.84 & 2810.60 & 0.000 \\
Interactions & & & & & \\
Treatments·Time & 845.22 & 20 & 42.27 & & \\
Residual & 44.66 & 30 & 1.49 & & \\
Total (corrected) & 18162.70 & 59 & & & \\
\hline
\end{tabular}

Since the $p$-values are lower than 0.05 (statistical significance), the main effects have a statistically significant influence on TPH concentration with a 95.0\% of confidence level. Furthermore, the interaction between Treatments and Time is statistically significant.

Therefore, multiple comparisons were developed to determine which levels of each factor are significantly different from the others. Table 3 presents the result of the multiple ranks for the factor Treatments, where all TPH values of both replicas at all times of the test $\mathrm{M}$ were averaged. 
Table 3. Multiple rank tests for the levels of the factor Treatment in test M.

\begin{tabular}{|c|c|c|c|c|}
\hline Treatments & Mean $\left(\mathrm{g} \cdot \mathrm{kg}^{-1}\right)$ & $\begin{array}{l}\text { Lower Limit } \\
\left(\mathrm{g} \cdot \mathrm{kg}^{-1}\right)\end{array}$ & $\begin{array}{l}\text { Upper Limit } \\
\left(\mathrm{g} \cdot \mathrm{kg}^{-1}\right)\end{array}$ & $\begin{array}{c}\text { Homogeneous } \\
\text { Groups }\end{array}$ \\
\hline $\mathrm{u} 8 \%-\mathrm{C} / \mathrm{N}=120$ & 36.65 & 35.86 & 37.44 & $X$ \\
\hline $\mathrm{u} 12 \%-\mathrm{C} / \mathrm{N}=180$ & 37.25 & 36.46 & 38.04 & $x X$ \\
\hline $\mathrm{u} 15 \%-\mathrm{C} / \mathrm{N}=180$ & 38.15 & 37.36 & 38.94 & $X X$ \\
\hline $\mathrm{u} 12 \%-\mathrm{C} / \mathrm{N}=120$ & 38.48 & 37.69 & 39.27 & X \\
\hline $\mathrm{u} 8 \%-\mathrm{C} / \mathrm{N}=180$ & 43.28 & 42.49 & 44.07 & $X$ \\
\hline $\mathrm{u} 15 \%-\mathrm{C} / \mathrm{N}=120$ & 44.36 & 43.57 & 45.15 & $X$ \\
\hline \multicolumn{5}{|c|}{ Standard Deviation: 0.385823} \\
\hline
\end{tabular}

The last column shows four homogenous groups, identified by columns of Xs. Within each column, the levels of the factor Treatment have no statistically significant differences. Looking at the data, results show that different combinations of water content and $\mathrm{C} / \mathrm{N}$ ratio give a significant influence on diesel oil removal.

Figure 3 presents a plot of TPH concentration by levels of the factor Time.

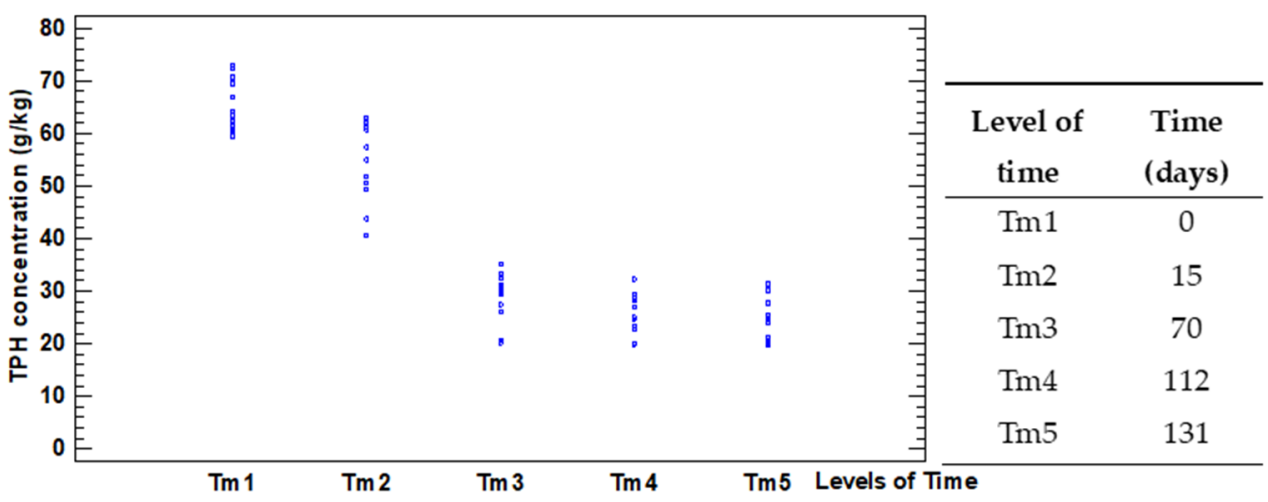

Figure 3. Scatterplot of TPH concentration by levels of the factor Time.

Despite the levels of the factor Time present statistical differences regarding the means of TPH concentration, there is an evident change in the trend of the mean ranks after the third level of time (70 days). After this time, although the means of hydrocarbons concentration slightly continue to decrease, the values of TPH concentration have tiny changes compared with the previous level.

Since different combinations of water content and carbon to nitrogen ratio influence the removal of the hydrocarbons, it is of interest to know which combination of treatment and time would ensure better results for any process period. Figure 4 shows the interactions of both factors.

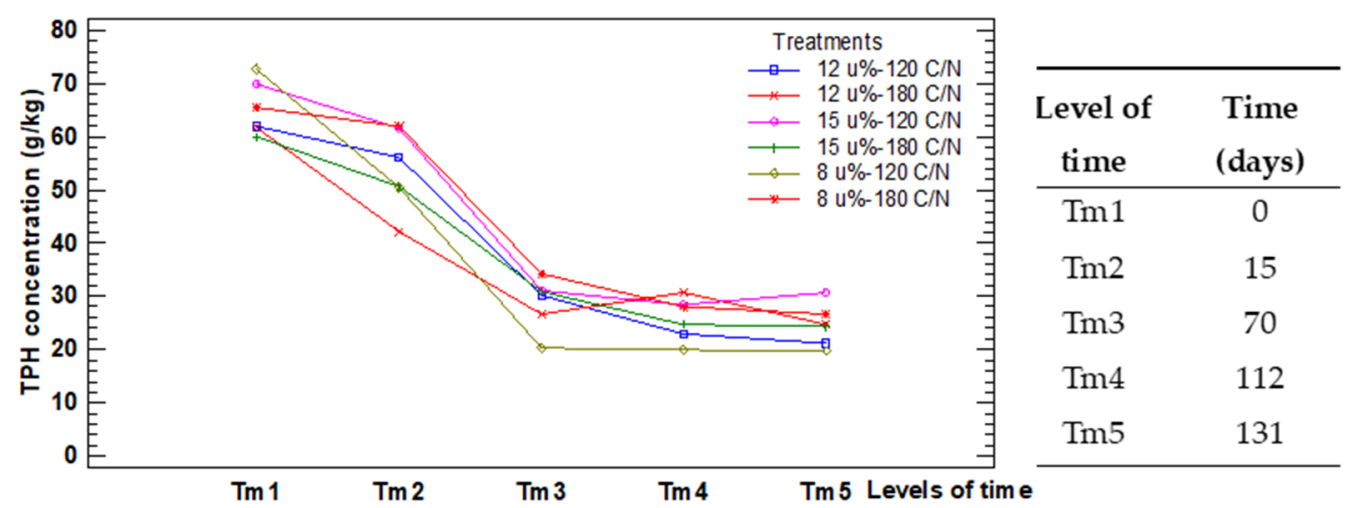

Figure 4. Interaction plot for the factors in test $\mathrm{M}$. 
The lines which represent the levels of Treatments are not parallel, but they cut each other. This corroborates the interaction reported in the ANOVA table and indicates that during the process, some treatments alternated their order of degradation regarding the others. The model assumptions are verified in Appendix A.

\subsubsection{Test B}

Table 4 reports the ANOVA for test $B$.

Table 4. ANOVA for test B.

\begin{tabular}{cccccc}
\hline Source & $\begin{array}{c}\text { Sum of } \\
\text { Squares }\end{array}$ & Df & $\begin{array}{c}\text { Mean } \\
\text { Square }\end{array}$ & F-Ratio & $p$-Value \\
\hline Main Effects & & & & & 0.000 \\
Treatments & 23.77 & 5 & 4.75 & 11.54 & 0.000 \\
$\quad$ Time & 315.93 & 4 & 78.98 & 2.08 & 0.012 \\
Interactions & & & & & \\
Treatments·Time & 17.09 & 20 & 0.85 & & \\
Residual & 31.71 & 77 & 106 & & \\
Total (corrected) & 389.30 & 10.41 & & \\
\hline
\end{tabular}

Since the $p$-values of all the sources are lower than 0.05 , the main effects have a statistically significant influence on TPH concentration with a $95.0 \%$ of confidence level. Furthermore, the interaction between Treatments and Time is also statistically significant.

The multiple comparisons procedure was developed to determine which levels of each factor are different from the others. Table 5 presents the result of the multiple ranks for the factor Treatments, where all TPH values of four replicas at all times of test B were averaged.

Table 5. Multiple rank tests for the levels of the factor Treatment in test B.

\begin{tabular}{|c|c|c|c|c|c|}
\hline Treatments & Mean $\left(\mathrm{g} \cdot \mathrm{kg}^{-1}\right)$ & $\begin{array}{l}\text { Standard } \\
\text { Deviation }\end{array}$ & $\begin{array}{l}\text { Lower Limit } \\
\quad\left(\mathrm{g} \cdot \mathrm{kg}^{-1}\right)\end{array}$ & $\begin{array}{l}\text { Upper Limit } \\
\left(\mathrm{g} \cdot \mathrm{kg}^{-1}\right)\end{array}$ & $\begin{array}{c}\text { Homogeneous } \\
\text { Groups }\end{array}$ \\
\hline Beef manure & 7.07 & 0.148 & 6.78 & 7.37 & $X$ \\
\hline Thalassia testudinum & 7.53 & 0.153 & 7.23 & 7.88 & X \\
\hline Sugarcane filter cake & 7.73 & 0.148 & 7.44 & 8.03 & $X X$ \\
\hline Sugarcane bagasse & 7.80 & 0.157 & 7.49 & 8.12 & $X X$ \\
\hline Coffee Pulp & 8.13 & 0.157 & 7.81 & 8.44 & $X$ \\
\hline Sawdust & 8.65 & 0.166 & 8.32 & 8.98 & $X$ \\
\hline
\end{tabular}

We identified four homogenous groups by $X$ columns. The results show that adding organic waste to the biopiles can significative influence the removal of the sludge hydrocarbons.

Due to the considerable amount of data overlapped in test $\mathrm{B}$, the means graph with the range of TPH concentrations for each level of the factor Time was plotted. Figure 5 represents this relationship.

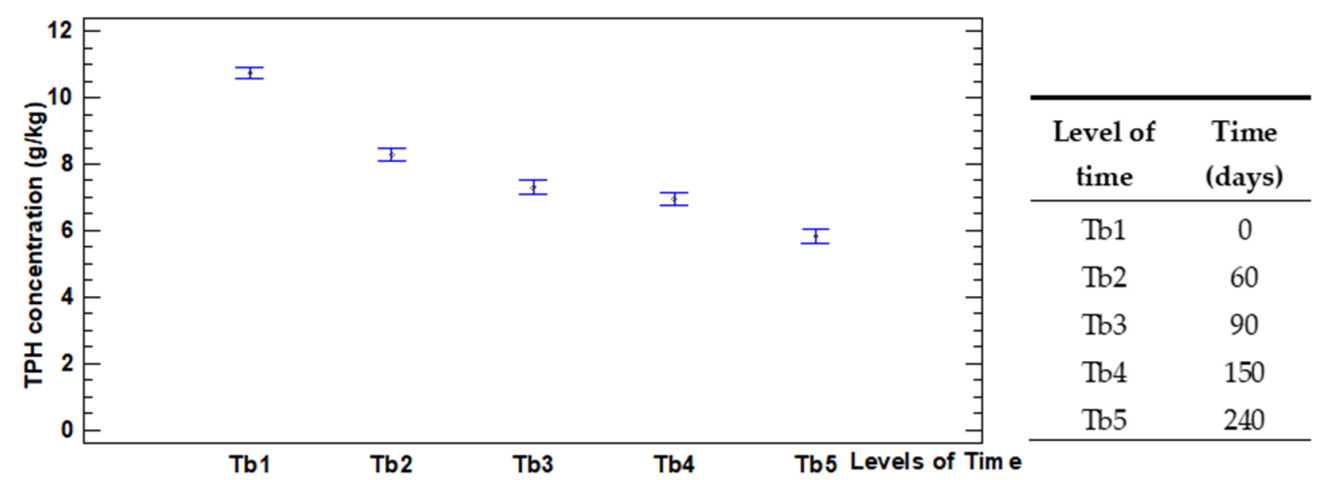

Figure 5. Overall TPH concentration by levels of the factor Time. 
The data show a quite constant decrement of the TPH concentration for all the treatments, except at Tb3 (90 days) and Tb4 (150 days) days, when the TPH concentration values are similar.

The $p$-values in Table 3 prove existing interaction effects among the different kinds of organic waste used as a bulking agent, the identification of which treatment ensures better removal of hydrocarbons, and when it is relevant. Figure 6 reports the interactions of both factors.

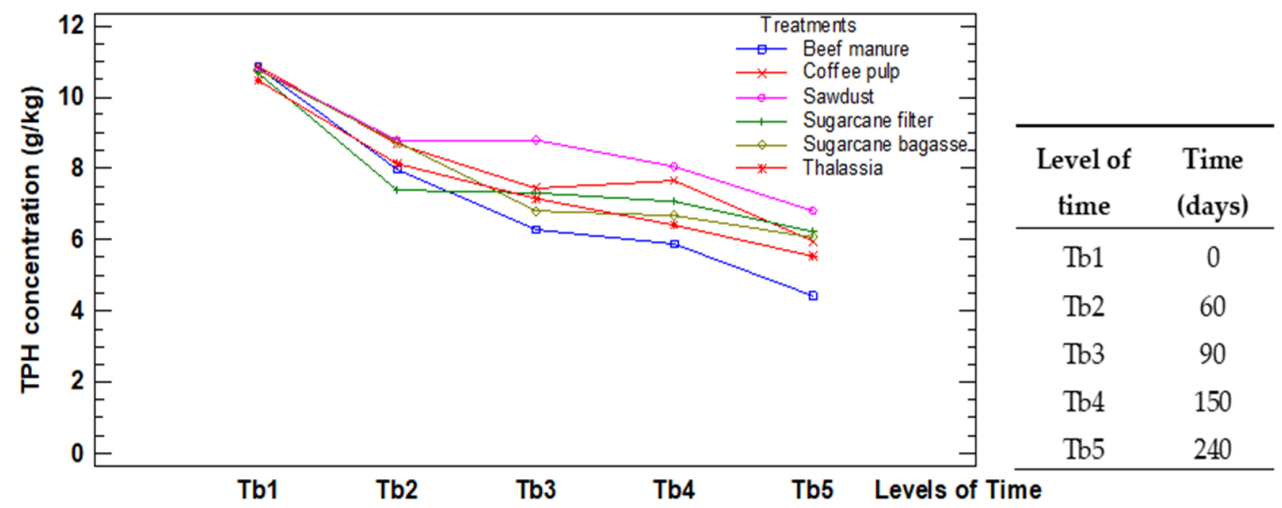

Figure 6. Interaction plot for the factors in test B.

The lines which represent the levels of treatments were crossed by each other repeatedly within the levels of time. This confirms the aforesaid interaction reported in the ANOVA table. These results invite to the later discussion about the comparison among the treatments. The model assumptions are verified in Appendix B.

\subsection{Kinetics Analysis Results}

This study modelled the reaction rate with the first and second-order models, to check whether one model was more reliable and robust than the other.

\subsubsection{Kinetic Analysis of Test M}

Table 6 presents the kinetic parameters for the response variable in test $\mathrm{M}$. In both models (first and second-order), the following parameters can be compared: degradation rate constant $(k)$, half lifetime $\left(t_{1 / 2}\right)$, and coefficient of determination $\left(R^{2}\right)$

Table 6. Kinetic parameters for the factor Treatments in test M.

\begin{tabular}{|c|c|c|c|c|c|c|c|}
\hline \multirow{2}{*}{ Kinetic Model } & \multirow{2}{*}{ Parameters } & \multicolumn{6}{|c|}{ Treatments } \\
\hline & & M1 & M2 & M3 & M4 & M5 & M6 \\
\hline \multirow{3}{*}{ First-order } & $\mathrm{k}\left(\mathrm{d}^{-1}\right)$ & 0.0115 & 0.0066 & 0.0080 & 0.0074 & 0.0082 & 0.0070 \\
\hline & $t_{1 / 2}(d)$ & 60 & 105 & 76 & 94 & 85 & 99 \\
\hline & $R^{2}$ & 0.75 & 0.90 & 0.91 & 0.84 & 0.92 & 0.84 \\
\hline \multirow{3}{*}{ Second-order } & $\mathrm{k}\left(\mathrm{kg} \cdot \mathrm{g}^{-1} \cdot \mathrm{d}^{-1}\right)$ & 0.0003 & 0.0002 & 0.0002 & 0.0002 & 0.0002 & 0.0002 \\
\hline & $\mathrm{t}_{1 / 2}(\mathrm{~d})$ & 46 & 76 & 81 & 81 & 71 & 83 \\
\hline & $R^{2}$ & 0.85 & 0.90 & 0.93 & 0.85 & 0.90 & 0.90 \\
\hline
\end{tabular}

\subsubsection{Kinetic Analysis of Test B}

Table 7 reports the kinetic parameters for the response variable in test $\mathrm{B}$. 
Table 7. Kinetic parameters for the factor Treatments in test B.

\begin{tabular}{cccccccc}
\hline \multirow{2}{*}{ Kinetic Model } & Parameters & \multicolumn{5}{c}{ Treatments } \\
\cline { 3 - 8 } & & B1 & B2 & B3 & B4 & B5 & B6 \\
\hline \multirow{3}{*}{ First-order } & $\mathrm{k}\left(\mathrm{d}^{-1}\right)$ & 0.0023 & 0.0019 & 0.0022 & 0.0023 & 0.0036 & 0.0026 \\
& $\mathrm{t}_{1 / 2}(\mathrm{~d})$ & 301 & 365 & 315 & 301 & 193 & 267 \\
& $\mathrm{R}^{2}$ & 0.81 & 0.75 & 0.98 & 0.90 & 0.94 & 0.93 \\
\hline \multirow{3}{*}{ Second-order } & $\mathrm{k}\left(\mathrm{kg} \cdot \mathrm{g}^{-1} \cdot \mathrm{d}^{-1}\right)$ & 0.0003 & 0.0002 & 0.0003 & 0.0003 & 0.0005 & 0.0003 \\
& $\mathrm{t}_{1 / 2}(\mathrm{~d})$ & 310 & 468 & 314 & 307 & 185 & 319 \\
& $\mathrm{R}^{2}$ & 0.84 & 0.81 & 0.97 & 0.92 & 0.97 & 0.97 \\
\hline
\end{tabular}

\section{Discussion}

Many studies used the Design of Experiment (DOE) to assess the bioremediation process $[5,11,39,48-50]$; however, the idea of testing the influence of categorical factors throughout different levels received scarce attention. In previous studies, the classical factorial models as the response surfaces methodology (RSM) or Taguchi DOE were used to evaluate bioremediation runs. Despite these methods demonstrated to be suitable for optimization, they may present limitations when the levels of the factor analyzed are constituted by categories. The categorical factor using one-way ANOVA is widely applied since it manages categorical factors. However, this method fails when more than one factor is included in the experimental array and neglects the interaction effects.

The categorical multifactor implemented in the present research strikes an accurate balance between statistical robustness analysis and resource savings for the concept of avoiding analytical measurement of various parameters, usually required for the other DOE models. Instead of that, categories or labels built from the combination of interest predetermined variables should be useful especially in the early stages of bioremediation projects, where the effects of multiple ideas are tested at the same time. Furthermore, as can be noted in both tests, the DOE implemented can distinguish interactions between the factors Treatments and Time in agreement with the reported by Tellechea et al. [35]. This particularity should be useful to evaluate the hierarchical evolution of the Treatments candidates among the different levels of time contributing to addressing the decisionmaking process facing the stages of the project development and the technology scale-up.

Specifically, in test M, the Treatment M1 ( $8 \mathrm{WC} \%-120 \mathrm{C} / \mathrm{N})$ had the lowest TPH concentration at each level of time after the first 15 days. Likewise, after 71 days M3 $(12 \mathrm{WC} \%-120 \mathrm{C} / \mathrm{N})$ was ranked second with lower TPH concentration, suggesting not only the best degradation of the treatments with the less $\mathrm{C} / \mathrm{N}$ ratio but also the influence of water content in the first period of the run. These findings are consistent with the previous ones modelled by Raffa et al. [11] using an RSM model, confirming the accurateness of the evaluation method adopted. As commented in the results section, after the third month, the TPH concentration decreasing was negligible for all treatments. This could represent a crucial issue to estimate the times for the in situ exploitation of the technology.

In test B, in all treatments, the TPH concentration decreased until 240 days, with removal percentages between $40 \%$ and $60 \%$, values similar to the ones achieved by other authors $[1,5,26]$. The treatments order rank was B5, B6, B2, B1, B4, B3. Specifically, Treatment B5 (beef manure) was the one that reported the lowest TPH concentrations at 240 days, keeping this trend after 60 days. The means obtained for B5 presented marked statistical differences with the rest of the treatment, being the one with the mean lower limit interval under $7.0 \mathrm{~g} \cdot \mathrm{kg}^{-1}$. In contrast, B3 (sawdust) presented the worst TPH removal, keeping this trend after the 60 days, being the only treatment with the mean interval over $8.0 \mathrm{~g} \cdot \mathrm{kg}^{-1}$. Despite the rank order, the TPH means of B6, B2 and B1 do not present significative differences for a $95 \%$ confidence level. Furthermore, the differences between the levels in the factor Time evidence the evolution in the degradation process.

Regarding this issue, the kinetic evaluation derived from experimental runs at the laboratory scale is useful to estimate the time to obtain the pollutant removal [26,51]. 
Consequently, kinetics is considered crucial to the scale-up process, and for the final insitu application.

For both tests, this study took into account the reaction rate at the first and secondorder models. In general, the $\mathrm{R}^{2}$ values are high in both models for both tests, confirming that the application is satisfactory.

For test M, both kinetic models fit well. For the second-order model, the coefficients of determination are higher, except for M5. In the case of M2, the first and the second-order model have the same $\mathrm{R}^{2}$. The best fit is for M3 with $93 \%$ of the variability explained by the second-order model. Within this model, all the treatments gave similar results for the $\mathrm{k}$ value, with the $11 / 2$ values in the range 46-83 days, in agreement with values reported in similar studies [47].

In test $\mathrm{B}$, although both models fit well, it was found that the kinetic models in all treatments, except B3, had higher coefficients of determination, $\mathrm{R}^{2}$, for the secondorder model.

The best fit is for $\mathrm{B} 3$, B5, and B6, while the $\mathrm{B} 5$ has also a higher degradation rate and the shortest half-life $\left(t_{1 / 2}=185\right.$ days $)$ among all the treatments, in line with values achieved by other authors [26]. The half-life time of the other treatments is always over 300 days, being the treatment $\mathrm{B} 2$ with the highest value (468 days). The kinetic behaviour might be explained by the complex nature of oil sludge and the occurrence of complex biochemical mechanisms of hydrocarbon bioremediation [33].

The structured method implemented in this study enables to set up and evaluate two different experimental runs. In microcosms polluted with diesel oil, combinations of water content and carbon to nitrogen ratio were assumed as treatments. The treatment M1 $(8 \mathrm{WC} \%-120 \mathrm{C} / \mathrm{N})$ showed the best diesel oil removal, with the shortest half-life time and the highest degradation within the second-order kinetic model.

In the experimental runs on biopiles to bioremediate oily sludge supplementing different renewable organic wastes as treatments, the treatment B5 (biopile with beef manure as a bulking agent) showed the best hydrocarbons removal, with the shortest half-life time and the highest degradation within the second-order kinetic model.

The results validate the robustness of the framework used which should be applied to the evaluation of bioremediation runs based on categorical factors or labels as variables of interest.

\section{Conclusions}

The statistical analysis based on two factors assessed at different levels demonstrated its applicability to studies done in different operative conditions. Particularly, we focused on a laboratory experiment (microcosm) and an in-field test (biopiles) to evaluate the reliability of the proposed statistical analysis in testing the performance of biostimulation processes of contaminated soil. We pointed out the main limits of the DOE analysis and the ANOVA methods, suggesting a categorical multifactor approach.

The main result is the evidence of the analysis reliability; therefore, the current study has a methodological value, useful for future applications in the bioremediation fields, but not only.

Author Contributions: Conceptualization, D.J.C.R. and F.C.; methodology, D.J.C.R., O.G.B. and F.C.; software, D.J.C.R.; validation, O.G.B., F.C. and A.G.; formal analysis, M.D.; investigation, E.C.P., O.G.B., F.C. and A.G.; data curation, D.J.C.R., E.C.P., O.G.B. and F.C.; writing-original draft preparation, D.J.C.R.; writing-review and editing, D.J.C.R., F.C., O.G.B. and A.G.; visualization, M.D.; supervision, M.D., F.C. and O.G.B.; project administration, F.C. and E.C.P.; funding acquisition, F.C. and O.G.B. All authors have read and agreed to the published version of the manuscript.

Funding: Test M was funded by the project "Geophysical Methods to Monitor Soil Bioremediation" funded by the Italian Ministry of Foreign Affairs and International Cooperation in the frame of the Executive Programme of Scientific and Technological Cooperation between the Republic of India and the Italian Republic for the years 2017-2019—Significant Research". Test B was funded by the project "Pilot-Scale Evaluation of Biopile Ecotechnology for the Bioremediation of Oily Waste Using Local 
Texturizers." funded by the Environment Agency of the Cuban Ministry of Science, Technology, and Environment in the frame of the National Interest Program "Sustainable use of the components of Biological Diversity in Cuba 2017-2021".

Institutional Review Board Statement: Not applicable.

Informed Consent Statement: Not applicable.

Data Availability Statement: Not applicable.

Acknowledgments: The authors are personally grateful to Orlando Viera Ribot for his support during the monitoring and the analytical determinations in test $\mathrm{B}$.

Conflicts of Interest: The authors declare no conflict of interest.

\section{Appendix A}

This Appendix A describes the graphical check of the assumptions for test $\mathrm{M}$.

In Figure A1, a line for the probability density function for the fitted normal distribution has been superimposed on the histogram. As the top of the bars is relatively close to the line, the normal distribution fits well. Any patron diversity of random scatter has been observed in the verification of the independence of the residuals (Figure A2). On the other hand, the homoscedasticity (Figure A3) has been verified with a less than ideal pattern, but it has been analyzed with the transformation of the variable. In general, the assumptions of the model have been successfully verified.

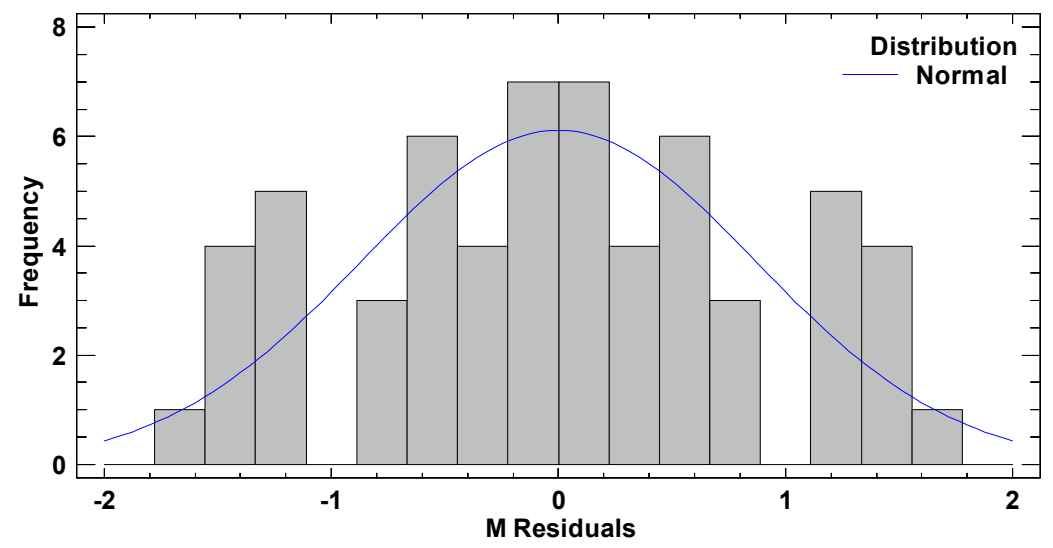

Figure A1. Frequency histogram for the residuals of the TPH concentration in test M.

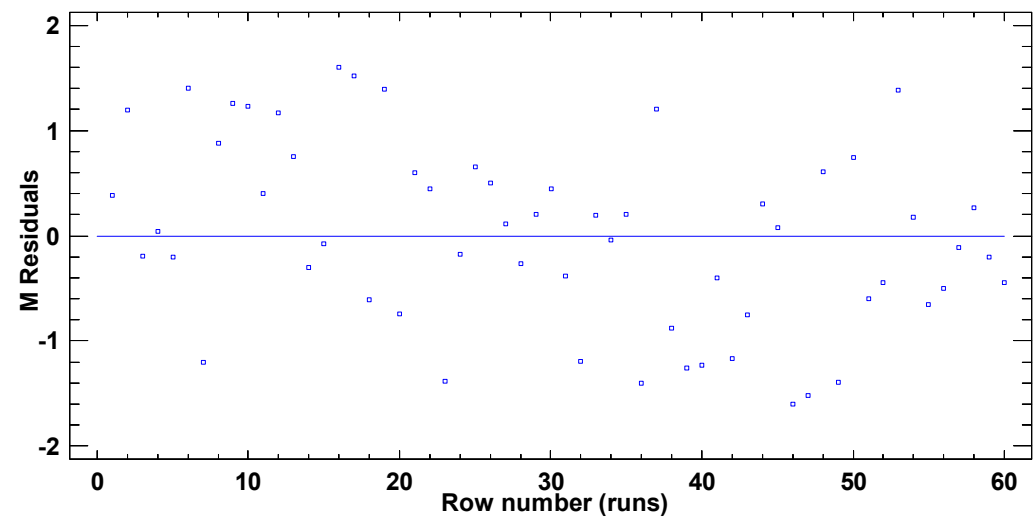

Figure A2. Residuals vs. row number (runs) for the TPH concentration in test M. 


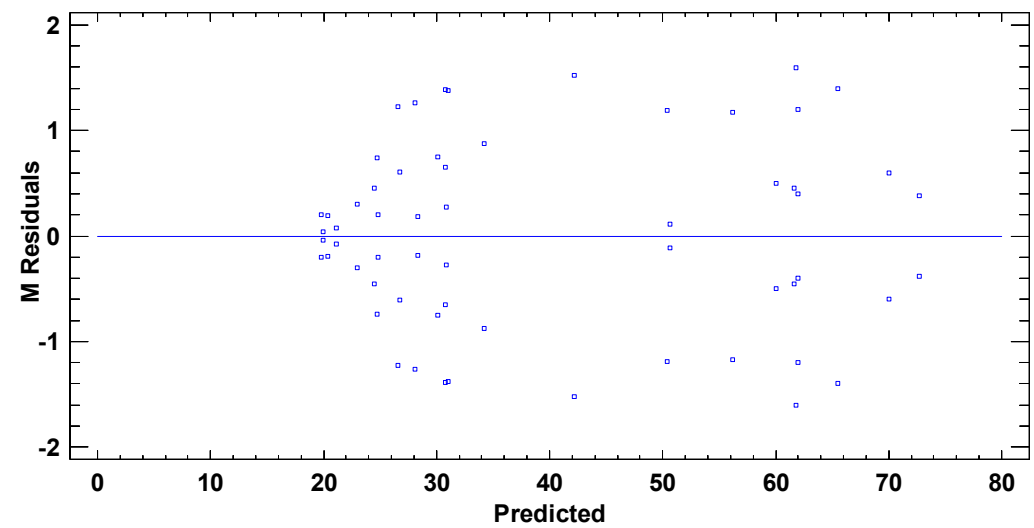

Figure A3. Residuals vs. predicted levels of the TPH concentration in test M.

\section{Appendix B}

This Appendix B describes the graphical check of the assumptions for test B.

In test B, the graphical pattern for normality (Figure A4) has been also corroborated with the values of both standard kurtosis and skewness ( -0.9255 and 0.3474 respectively), which were in the range expected for data from a normal distribution ( -2 to 2 ). Any pattern diversity of random scatter was observed in the verification of the independence of the residuals (Figure A5). Although Figure A6 represents a cloud of points barely less than perfect, there is not a clear general funnel-shaped pattern that contradicts the homoscedasticity assumption. The assumptions of the model have been successfully verified.

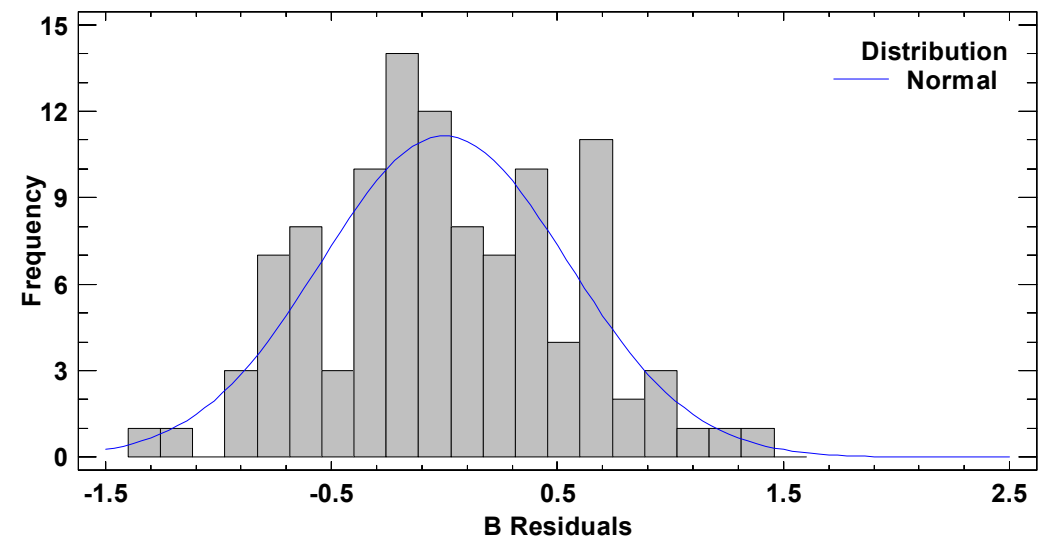

Figure A4. Frequency histogram for the residuals of the TPH concentration in test B.

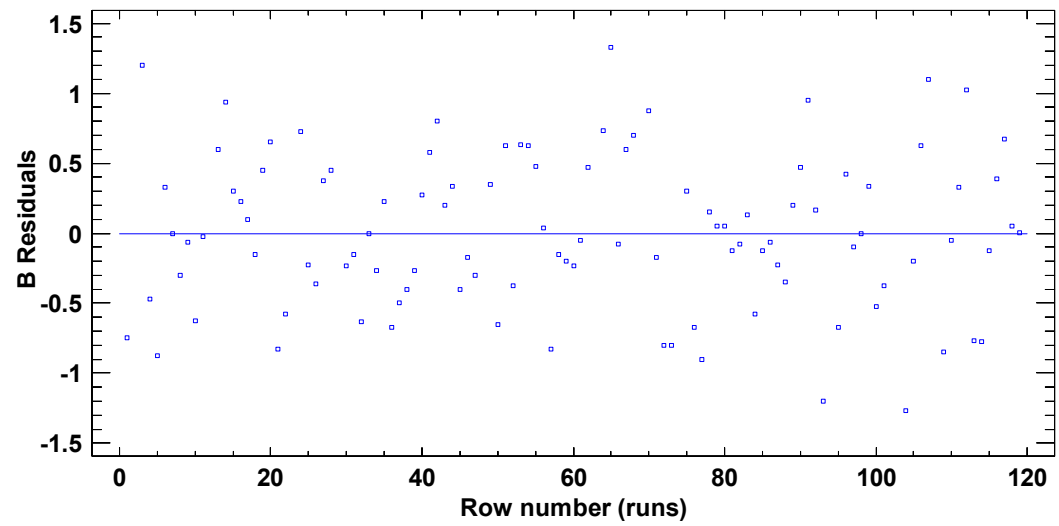

Figure A5. Residuals vs. row number (runs) for the TPH concentration in test B. 


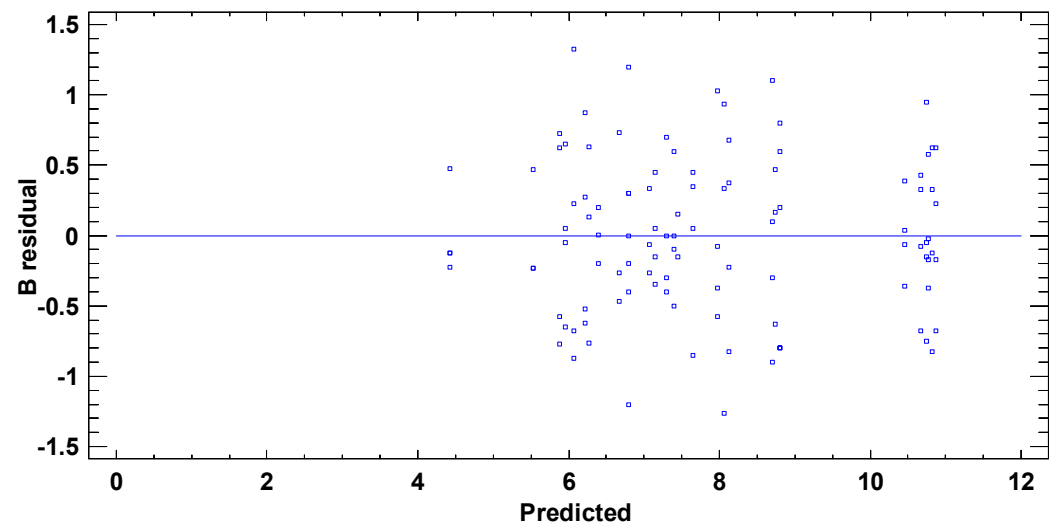

Figure A6. Residuals vs. predicted levels of the TPH concentration in test B.

\section{References}

1. Koolivand, A.; Abtahi, H.; Parhamfar, M.; Didehdar, M.; Saeedi, R.; Fahimirad, S. Biodegradation of high concentrations of petroleum compounds by using indigenous bacteria isolated from petroleum hydrocarbons-rich sludge: Effective scale-up from liquid medium to composting process. J. Environ. Manag. 2019, 248, 109228. [CrossRef] [PubMed]

2. Shahryar, J. Chapter 3: Environmental Impacts of the Petroleum Industry. In Petroleum Waste Treatment and Pollution Control; Shahryar, J., Ed.; Butterworth-Heinemann: Oxford, UK; Elsevier Inc.: Amsterdam, The Netherlands, 2017; Volume 3, pp. 86-115. ISBN 978-0-12-809243-9. [CrossRef]

3. Bosco, F.; Casale, A.; Mazzarino, I.; Godio, A.; Ruffino, B.; Mollea, C.; Chiampo, F. Microcosm evaluation of bioaugmentation and biostimulation efficacy on diesel-contaminated soil. J. Chem. Technol. Biotechnol. 2019, 94, 904-912. [CrossRef]

4. Hu, G.; Li, J.; Zeng, G. Recent development in the treatment of oily sludge from petroleum industry: A review. J. Hazard. Mater. 2013, 261, 470-490. [CrossRef] [PubMed]

5. Li, J.; Guo, C.; Lu, G.; Yi, X.; Dang, Z. Bioremediation of Petroleum-Contaminated Acid Soil by a Constructed Bacterial Consortium Immobilized on Sawdust: Influences of Multiple Factors. Water Air Soil Pollut. 2016, 227, 444. [CrossRef]

6. Kaczorek, E.; Smułek, W. Effective scale-up from liquid medium to composting process. Processes 2021, 9, 1130. [CrossRef]

7. Johnston, J.; Cushing, L. Chemical Exposures, Health, and Environmental Justice in Communities Living on the Fenceline of Industry. Curr. Environ. Health Rep. 2020, 7, 48-57. [CrossRef]

8. Castro, D.J.; Gutiérrez, O.; Poma, J.R.; Bermúdez, J.; Demichela, M. Environmental monitoring in a Cuban oil storage plant to characterize the hydrocarbons pollution exposure in the fence-line community. In Oil and Gas Industry, Proceedings of the 31st European and Safety Reliability (ESREL 2021), Angers, France, 19-23 September 2021; Castanier, B., Cepin, M., Bigaud, D., Berenguer, C., Eds.; Research Publishing Services: Singapore, 2021; pp. 2299-2304, ISBN 978-981-18-2016-8. [CrossRef]

9. Gospodarek, J.; Petryszak, P.; Kołoczek, H. The effect of the bioremediation of soil contaminated with petroleum derivatives on the occurrence of epigeic and edaphic fauna. Bioremediat. J. 2016, 20, 38-53. [CrossRef]

10. Margesin, R.; Zimmerbauer, A.; Schinner, F. Monitoring of bioremediation by soil biological activities. Chemosphere 2000, 40, 339-346. [CrossRef]

11. Raffa, C.M.; Chiampo, F.; Godio, A.; Vergnano, A.; Bosco, F.; Ruffino, B. Kinetics and Optimization by Response Surface Methodology of Aerobic Bioremediation. Geoelectrical Parameter Monitoring. Appl. Sci. 2020, 10, 405. [CrossRef]

12. Basak, G.; Hazra, C.; Sen, R. Biofunctionalized nanomaterials for in situ clean-up of hydrocarbon contamination: A quantum jump in global bioremediation research. J. Environ. Manag. 2020, 256, 109913. [CrossRef]

13. Poddar, K.; Sarkar, D.; Sarkar, A. Construction of potential bacterial consortia for efficient hydrocarbon degradation. Int. Biodeterior. Biodegrad. 2019, 144, 104770. [CrossRef]

14. Poi, G.; Shahsavari, D.; Aburto-Medina, A.; Mok, P.C.; Ball, A.S. Large scale treatment of total petroleum-hydrocarbon contaminated groundwater using bioaugmentation. J. Environ. Manag. 2018, 214, 157-163. [CrossRef]

15. Varjani, S.J.; Gnansounou, E.; Pandey, A. Comprehensive review on toxicity of persistent organic pollutants from petroleum refinery waste and their degradation by microorganisms. Chemosphere 2019, 188, 280-291. [CrossRef] [PubMed]

16. Adetutu, E.M.; Bird, C.; Kadali, K.K.; Bueti, A.; Shahsavari, E.; Taha, M.; Patil, S.; Sheppard, P.J.; Makadia, T.; Simons, K.L.; et al. Exploiting the intrinsic hydrocarbon-degrading microbial capacities in oil tank bottom sludge and waste soil for sludge bioremediation. Int. J. Environ. Sci. Technol. 2015, 12, 1427-1436. [CrossRef]

17. USEPA. Cleaning up the Nation's Waste Sites: Markets and Technology Trends; EPA 542-R-04-015; US Environmental Protection Agency: Washington, DC, USA, 2004.

18. Lim, M.W.; Lau, E.V.; Poh, P.E. A comprehensive guide of remediation technologies for oil contaminated soil-Present works and future directions. Mar. Pollut. Bull. 2016, 109, 14-45. [CrossRef] [PubMed]

19. Ossai, I.C.; Ahmed, A.; Hassan, A.; Shahul, F.; Ball, A.S. Remediation of soil and water contaminated with petroleum hydrocarbon: A review. Environ. Technol. Innov. 2020, 17, 100526. [CrossRef] 
20. Tran, H.-T.; Lin, C.; Bui, X.-T.; Ngo, H.-H.; Cheruiyot, N.K.; Hoang, H.-G.; Vu, C.-T. Aerobic composting remediation of petroleum hydrocarbon-contaminated soil. Current and future perspectives. Sci. Total Environ. 2021, 753, 142250. [CrossRef]

21. Calvo, C.; Rodríguez-Calvo, A.; Robledo-Mahón, T.; Manzanera, M.; González-López, J.; Aranda, E.; Silva-Castro, G.A. Biostimulation of crude oil-polluted soils: Influence of initial physicochemical and biological characteristics of soil. J. Environ. Sci. Technol. 2019, 16, 4925-4934. [CrossRef]

22. Yanto, D.H.Y.; Hidayat, A.; Tachibana, S. Periodical biostimulation with nutrient addition and bioaugmentation using mixed fungal cultures to maintain enzymatic oxidation during extended bioremediation of oily soil microcosms. Int. Biodeterior. Biodegrad. 2017, 116, 112-123. [CrossRef]

23. Wu, M.; Dick, W.A.; Li, W.; Wang, X.; Yang, Q.; Wang, T.; Xu, L.; Zhang, M.; Chen, L. Bioaugmentation and biostimulation of hydrocarbon degradation and the microbial community in a petroleum-contaminated soil. Int. Biodeterior. Biodegrad. 2016, 107, 158-164. [CrossRef]

24. Juwarkar, A.A.; Singh, S.K.; Mudhoo, A.A. A comprehensive overview of elements in bioremediation. Rev. Env. Sci. Biotechnol. 2010, 9, 215-288. [CrossRef]

25. Haghollahi, A.; Hassan, A.F.; Schaffie, M. The effect of soil type on the bioremediation of petroleum contaminated soils. J. Environ. Manag. 2016, 180, 197-201. [CrossRef] [PubMed]

26. Bidja Abena, M.T.; Li, T.; Shah, M.N.; Zhong, W. Biodegradation of total petroleum hydrocarbons (TPH) in highly contaminated soils by natural attenuation and bioaugmentation. Chemosphere 2019, 234, 864-874. [CrossRef] [PubMed]

27. Casale, A.; Bosco, F.; Chiampo, F.; Franco, D.; Ruffino, B.; Godio, A.; Pujari, P.R. Soil microcosm set up for a bioremediation study. In Proceedings of the Sixth International Conference on Advances in Bio-Informatics, Bio-Technology and Environmental Engineering-ABBE 2018, Zurich, Switzerland, 28-29 April 2018; The IRED: New York, NY, USA, 2018; pp. 12-15. [CrossRef]

28. Simpanen, S.; Dahl, M.; Gerlach, M.; Mikkonen, A.; Malk, V.; Mikola, J.; Romantschuk, M. Biostimulation proved to be the most efficient method in the comparison of in situ soil remediation treatments after a simulated oil spill accident. Environ. Sci. Pollut. Res. 2016, 23, 25024-25038. [CrossRef]

29. Rene, E.R.; Jo, M.S.; Kim, S.H.; Park, H.S. Statistical analysis of main and interaction effects during the removal of BTEX mixtures in batch conditions, using wastewater treatment plant sludge microbes. Int. J. Environ. Sci. Technol. 2007, 4, 177-182. [CrossRef]

30. Box, G.E.; Hunter, W.G.; Hunter, J.S. Statistics for Experimenters, 2nd ed.; John Wiley \& Sons, Inc.: New York, NY, USA, 1978; pp. 1-640.

31. Montgomery, D.C. Design and Analysis of Experiments, 9th ed.; John Wiley \& Sons, Inc.: Scottsdale, AZ, USA, 2020 ; pp. 1-752. ISBN 978-1-119-32093-7.

32. Gutiérrez, H.; de la Vara, R. Analysis and Design of Experiments, 3rd ed.; MCGRAW-HILL INTERAMERICANA, S.A., Ed.; McGraw-Hill: México City, Mexico, 2012; pp. 1-506, ISBN 978-607-15-0725-9. (In Spanish)

33. Gutiérrez, O.; Castro, D.; Viera, O.; Casals, E.; Rabassa, D. Kinetic of hydrocarbon degradation by biopile at a bench-scale. Tecnol. Química 2021, 41,349-369.

34. Komilis, D.P.; Vrohidou, A.E.K.; Voudrias, E.A. Kinetics of Aerobic Bioremediation of a Diesel-Contaminated Sandy Soil: Effect of Nitrogen Addition. Water Air Soil Pollut. 2010, 208, 193-208. [CrossRef]

35. Tellechea, F.R.F.; Martins, M.A.; da Silva, A.A.; Forestieri de Gama-Rodrigues, E.; Martins, M.L.M. Use of sugarcane filter cake and nitrogen, phosphorus and potassium fertilization in the process of bioremediation of soil contaminated with diesel. Env. Sci. Pollut. Res. 2016, 23, 18027-18033. [CrossRef]

36. Gholami-Shiri, J.; Mowla, D.; Dehghani, S.; Setoodeh, V. Exploitation of novel synthetic bacterial consortia for biodegradation of oily-sludge TPH of Iran gas and oil refineries. J. Environ. Chem. Eng. 2021, 19, 1263-1276. [CrossRef]

37. Oualha, M.; Al-Kaabi, N.; Al-Ghouti, M.; Zouari, N. Identification and overcome of limitations of weathered oil hydrocarbons bioremediation by an adapted Bacillus sorensis strain. J. Environ. Manag. 2019, 250, 109455. [CrossRef]

38. Aziz, S.; Ali, M.I.; Farooq, U.; Jamal, A.; Liu, F.J.; He, H.; Guo, H.; Urynowicz, M.; Huang, Z. Enhanced bioremediation of diesel range hydrocarbons in soil using biochar made from organic wastes. Env. Monit. Assess. 2020, 192, 569. [CrossRef] [PubMed]

39. Zhang, C.; Wu, D.; Ren, H. Bioremediation of oil contaminated soil using agricultural wastes via microbial consortium. Sci. Rep. 2020, 10, 9188. [CrossRef] [PubMed]

40. Castro, D.; Gonález, Y.; Gutiérrez, O.; Viera, O.; Casals, E.; Rabassa, D.; Demichela, M. QFD to determine experimental biopiles requirements, evaluated at bench-scaleas a resilient strategy against soil contamination with oil residues. Chem. Eng. Trans. 2021, accepted.

41. USEPA. Chapter IV: Biopiles. In How to Evaluate Alternative Cleanup Technologies for Underground Storage Tank Sites. A Guide for Corrective Action Plan Reviewers; EPA 510-B-17-003; United Stated Environmental Protection Agency (USEPA): Washington, DC, USA, 2017; pp. 1-27.

42. Gutiérrez, O.; Castro, D.; Viera, O.; Casals, E.; Rabassa, D. Engineering design and assembly of experimental units for the bioremediation of petroleum waste on a bench-scale. Tecnol. Química 2020, 40, 546-562.

43. Casals, E.; Rabassa, D.; Viera, O.; Gutiérrez, O.; Castro, D. Abiotic factors behavior in petrolized residues biorremediation by biopiles at semi-pilot scale. Cent. Azúcar 2020, 47, 36-46.

44. NC 20:1999; Geotechnics: Determination of the Granulometry of Soils; Norma Cubana (Cuban Standard). Oficina Nacional de Normalización (ONN): Havana, Cuba, 1999. (In Spanish) 
45. NC 59:2000; Geotechnics. Geotechnical Classification of Soils; Norma Cubana (Cuban Standard). Oficina Nacional de Normalización (ONN): Havana, Cuba, 2000. (In Spanish)

46. NC 819: 2017; Management of Waste from the Bottom of Oil Storage Tanks and Its Derivatives; Norma Cubana (Cuban Standard). Oficina Nacional de Normalización (ONN): Havana, Cuba, 2017. (In Spanish)

47. Bosco, F.; Casale, A.; Chiampo, F.; Godio, A. Removal of diesel oil in soil microcosms and implication for geophysical monitoring. Water 2019, 11, 1661. [CrossRef]

48. Lin, T.C.; Pan, P.T.; Cheng, S.S. Ex situ bioremediation of oil-contaminated soil. J. Hazard. Mater. 2010, 116, 27-34. [CrossRef]

49. Gomez, F.; Sartaj, M. Optimization of field scale biopiles for bioremediation of petroleum hydrocarbon contaminated soil at low temperature conditions by response surface methodology (RSM). Int. Biodeterior. Biodegrad. 2014, 89, 103-109. [CrossRef]

50. Khayati, G.; Barati, M. Bioremediation of Petroleum Hydrocarbon Contaminated Soil: Optimization Strategy Using Taguchi Design of Experimental (DOE) Methodology. Environ. Process. 2017, 4, 451-461. [CrossRef]

51. Poorsoleiman, M.S.; Hosseini, S.A.; Etminan, A.; Abtahi, H.; Koolivand, A. Effect of two-step bioaugmentation of an indigenous bacterial strain isolated from oily waste sludge on petroleum hydrocarbons biodegradation: Scaling-up from a liquid mineral medium to a two-stage composting process. Environ. Technol. Innov. 2020, 17, 100558. [CrossRef] 